\title{
Analysis of Betawi Language Interference on the Morphology of Adolescent Speech in Jakarta
}

\author{
Iskandarsyah Siregar 8 (D) \\ Head of Center for Nusantara Socioculture Studies, Universitas Nasional, Jakarta, Indonesia \\ $\triangle$ Corresponding Author: Iskandarsyah Siregar, E-mail: regaranggi@presidency.com
}

\author{
ARTICLE INFORMATION \\ Received: July 02, 2021 \\ Accepted: August 25, 2021 \\ Volume: 3 \\ Issue: 8 \\ DOI: $10.32996 /$ jhsss.2021.3.8.7
}

\section{KEYWORDS}

Interference, Betawi Language, Speech Morphology, Adolescents

\section{ABSTRACT}

This research aims to identify the interference of Betawi language elements to the morphological variables of adolescent speech in Jakarta. The present study uses a qualitative method approach using descriptive analysis techniques. The subjects in the current study were adolescents who were in Jakarta. The data analyzed in this study are words in a sentence that interfered with the Betawi language, which contained aspects of affixation, reduplication, composition, and acronyms. The research findings indicate a Betawi language morphological interference to the morphological variables of speech from the aspects of affixation and reduplication. The results of other studies indicate that there is a Betawi language morphological interference to the morphological variables of speech from the affixation aspect, namely, words affixed with prefixes, suffixes, and confixes. The Betawi language morphological interference with the morphology of speech from the reduplication aspect, namely, dwilingga, can also be seen. The researcher did not find any Betawi language morphological interference to the morphology of speech from the aspects of composition and on the acronym teenagers speak in Jakarta.

\section{Introduction}

Language is a tool to convey messages from articulators to auditors. Thus, the essence of the language process is how a message can convey effectively and efficiently using the best way. Alwasilah (1989, p. 9) stated that language consists of a series of symbols to communicate with fellow humans because humans have feelings, ideas, and desires. Both Indonesian (BI) and regional languages $(B D)$ are part of the nation's culture and have their place in the Indonesian cultural treasures that need to be protected and fostered. This is in line with the explanation of Chapter XV, Article 36 of the 1945 Constitution, which states that Indonesian is the language of the state and the regional language used as a means of communication and which is maintained by the people who use it and by the state as part of the living national culture.

In its implementation, the use of two languages side by side will potentially cause language distortion. This form of language distortion is called language interference. Chaer and Agustina (2004, p. 120) said that interference is the use of other language elements in a language, which is considered an error because it deviates from the rules or rules of the language used.

Language is always undergoing development and change. These developments and changes occur due to various factors, such as social, economic, and cultural dynamics. Language development is rapid in science and technology, politics, and economics, and other elements can cause a language to be influenced by other languages. The process of mutual influence between one language and another cannot be avoided. Language as an integral part of the culture cannot be separated from the above problems. The mutual influence between languages must occur, for example, the language's vocabulary, considering that vocabulary has an open nature. Weinrich argued (in Chaer and Agustina 1995, p. 159) that a language contact is an event of using two languages by the same speaker alternately. Through the process of language contact, there is a transfer of one language element into another language that includes all levels. As a consequence, the process of borrowing and influencing other language elements cannot be avoided. It is assumed that if two or more languages are used interchangeably by the same

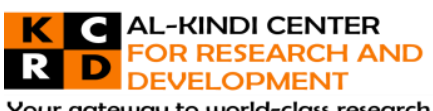

Your gateway to world-class research

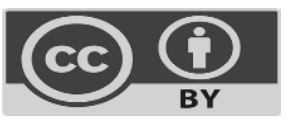

Published by Al-Kindi Center for Research and Development. Copyright (c) the author(s). This open access article is distributed under a Creative Commons Attribution (CC-BY) 4.0 license 
speaker, it can be said that the languages are in contact with each other. In every language contact, there is a process of mutual influence between one language and another. As a result, interference will arise, both verbally and in writing.

Weinreich (1953) first stated that the term interference refers to the contact of a language system in connection with the contact of the language with other language elements carried out by bilingual speakers. Multilingual speakers are speakers who can use multiple languages interchangeably. In this case, Weinreich considers interference as a symptom of deviations from linguistic norms that occur in a speaker's use of language as a result of his recognition of more than one language. This happened as a result of language contact.

In the interference phenomenon, the use of other language elements in using a language is considered an error because it deviates from the rules of the language used. This tendency is relevant and connected to the speaker's ability to use a certain language so that other languages influence him. Usually, this interference occurs in using a second language, and what is interfered in that second language is the first or mother tongue.

Linguists see morphological interference as the most common interference. This interference occurs in word-formation by absorbing the affixes of other languages. For example, we often hear the words hit, crash, greatness, smallness, overpriced, real, disbanded, and two. These forms are said to be forms of interference because they have the correct form: being hit, too big, too small, too expensive, serious, separated (dispersed), and the two of them. Based on the data above, it is clear that the wordformation process, called morphological interference, has a basic form in Indonesian vocabulary with affixes from regional or foreign languages.

Yusuf and Sugandhi (2011, p. 77) stated that adolescence is a transition from childhood to adulthood wherein all aspects/functions are developed to enter the period. Adolescence is a transitional period of development during childhood and adulthood, starting from puberty, which is marked by rapid changes in various aspects of development, both physical and psychological. Therefore, the present study aims to identify the interference of Betawi language elements to the morphological variables of adolescent speech in Jakarta.

\section{Literature Review}

There are several expert views regarding interference and are considered relevant to this issue. Among them are as follows: 1) Osgood and Sebeok (1965, p. 139) showed speakers of equal language ability if bilingual speakers have the same ability to language 1 with language 2, meaning that bilingual speakers have no difficulty using both languages whenever needed because the actions of the two languages are separate and work independently. Meanwhile, speakers with multiple language skills, namely, speakers whose language skills are lower or different from language skills 1, meaning that speakers have difficulty using language 2 because it is influenced by language 1. 2) Poerwadarminto in Pramudya (2006, p. 27) stated that interference comes from English interference, meaning mixture, violation, and obstacle. Interference, in general, can be interpreted as a mixture in the field of language. The mixture in question is the mixing of two languages or the mutual influence between the two languages. 3) Hartman and Stork (1972, p. 15) do not call interference a distraction or chaos, but mistakes that occur as a result of bringing the spoken habits of the mother tongue or dialect into the second language. 4) William Mackey (educational linguist) argued that interference is a symptom of the use of elements of one language in another when a speaker uses those languages.

The main factor that can cause interference is the difference between the source language and the target language. The difference is not only in the structure of the language but also in the diversity of the vocabulary. The symptoms themselves occur as a result of the speaker's recognition or identification of certain elements of the source language, then use them in the target language. Furthermore, any language has never been in a certain state. It always changes according to the changing times.

Interference is considered a symptom that often occurs in language use. Interference can occur when speakers use the first language when speaking in the second language; the use of their mother tongue when speaking Indonesian results in irregularities in the structure of the language. This structural deviation can cause interference. The factors behind the emergence of interference include the following:

a. The habit of speakers to use regional languages as their first language.

Hortman and Stoork in Alwasilah (1985, p. 131) consider interference as a mistake due to the carrying over of the spoken habits of the mother tongue or dialect into the second language or dialect. Speakers unconsciously use regional languages when speaking in the context of Indonesian. Speakers can avoid this because the mother tongue words used by bilinguals already have their equivalents in Indonesian. Language interference that occurs due to the speaker's habit of using regional languages can be seen in word-formation (morphology) and sentence structure (syntax).

b. Speakers want to show regional nuances in their conversations.

There is comfort when speaking in the local language with people from the same area (for example, both speak Balinese). With the use of regional language, conversations will be felt familiar by the speaker. At that time, sometimes, words from Indonesian 
were mixed with words from Balinese. For example, in the sentence Ampura Pak, the pole cannot go with them. In addition to showing regional nuances, the speakers also intend to refine the meaning.

In addition to the factors above, according to Weinreich (1970, p. 64-65), several factors cause interference, including:

a. Bilingualism of the participants said

The bilingualism of the speech participants is the basis for interference and various other influences from the source language, from both regional and foreign languages. This is due to language contact in bilingual speakers, which in turn can cause interference.

b. The lack of loyalty of the recipient's language user

The lack of bilingualism's loyalty to the recipient's language leads to a less positive attitude. This causes the uncontrolled neglect of the rules of the receiving language used and the uncontrolled taking of the source language elements that the speaker controls. As a result, interference will appear in the receiving language used by speakers, both orally and in writing.

c. Insufficient vocabulary for the recipient's language

The vocabulary of a language is generally limited to the expression of the various society concerned and other aspects of life that it is familiar with. Therefore, if the community associates with new aspects of life from the outside, they will meet and learn new concepts deemed necessary. Because they do not have the vocabulary to express the new concept, they use the vocabulary of the source language to express it; deliberately, language users will absorb or borrow the vocabulary of the source language to express the new concept. The factor of the recipient language's insufficient or limited vocabulary to express a new concept in the source language tends to cause interference.

Interference that arises because of the need for new vocabulary tends to be done deliberately by language users. New vocabulary obtained from this interference tends to be integrated more quickly because these elements are indispensable to enrich the vocabulary of the recipient's language.

d. Disappearance of rarely used words

The vocabulary in a language that is rarely used tends to disappear. If this happens, it means that the vocabulary of the language in question will become increasingly thin. If the language is exposed to new concepts from outside, on the one hand, it will reuse the vocabulary that has disappeared, and on the other hand, it will cause interference, namely, the absorption or borrowing of new vocabulary from the source language.

Interference caused by the disappearance of vocabulary that is rarely used will result in interference caused by the insufficient vocabulary of the recipient's language, namely, absorption or borrowed elements will be integrated more quickly because these elements are needed in the recipient's language.

e. The need for synonyms

Synonyms in language have an important function as variations in word choice to avoid using the same word repeatedly. With the existence of synonymous words, language speakers can have variations in the vocabulary that is used to avoid repeated use of words. Because the existence of this synonym is quite important, language users often interfere with the form of absorption or borrowing of new vocabulary from the source language to provide synonyms in the receiving language. Thus, the need for synonymous vocabulary can encourage interference.

f. Prestige source language and style

The prestige of the source language can encourage interference because the language user wants to show that he can master the language that is considered prestigious. The prestige of the source language can also be related to the language user's desire to be stylish in language. Interference that arises because of this factor is usually the use of source language elements in the receiving language used.

g. Carrying out habits in the mother language

The habitual habit of using the mother tongue in the receiving language that is being used generally occurs due to a lack of language control and a lack of mastery of the recipient's language. This can happen to bilinguals learning a second language, both national and foreign languages. In the use of the second language, language speakers sometimes lack control. Because of their bilingualism, sometimes when speaking or writing in a second language what appears is the vocabulary of their mother tongue which they have already known and mastered.

Three important elements play a role in the interference process, namely: 
a. The source language or commonly known as the donor language. Donor language is the dominant language in a language community so language elements are often borrowed for the benefit of inter-community communication.

b. The target language or the recipient language. Absorbent language is a language that accepts these foreign elements and then harmonizes the rules of pronunciation and writing into the language of the recipient.

c. Elements of absorption or importation. What is meant here is the transfer of elements from a foreign language to a receiving language.

The Betawi language is one of the many regional languages in Indonesia. This language is still used as an everyday language by some people who live in the DKI Jakarta Province and outside the administrative areas of DKI Jakarta, such as West Java and Banten. The use of Betawi language outside the administrative area of DKI Jakarta is seen in transitional or border areas, such as Citayam, Bogor, and Tangerang, Banten. The Betawi language can be simply divided into two sub-dialects that are called innercity sub-dialects and suburban sub-dialects. The suburban sub-dialect, which is used on the outskirts of Jakarta, is also often called "Betawi Ora" or "Melayu Ora." The term arises because, in the suburbs, the word ora or not which comes from the Javanese language, is often used side by side with a word that means kaga '(no). This designation illustrates that in the subdialect, many words come from the Javanese language, which is used in the city's suburbs and not used in the sub-dialect in the city. Apart from some differences in vocabulary between the sub-dialects, there are also differences in phonological features that separate the two sub-dialects. In the sub-dialect of Dalam Kota, most of the final vowels, which in Indonesian are pronounced (a), are pronounced with the vowel e, such as aye (me), ape (what), mange (why), and so on.

\section{Methods}

This research used qualitative methods using descriptive analysis techniques. Qualitative descriptive research methods are useful for describing qualitative information and descriptive history. This research method is used to analyze social activities and phenomena that exist in the community. This method seeks to translate data related to social conditions, the connection between the variables that occur, and the emergence of existing facts and their consequences for the environment and several aspects of everyday life. The expected results in this type of research are factual, empirical information.

Nazir (2009: 54) argued that the descriptive method is a method of examining the status of a group of people, an object, a set of conditions, a system of thought, or a class of events in the present. The objective of the research is to describe the form of the Betawi language morphological interference to the morphological variables of adolescent speech in Jakarta from the aspects of affixation and reduplication.

The research data analyzed in the current study were words in a sentence interfered with by the Betawi language that contained aspects of affixation and reduplication. The data source of this research is adolescents in Jakarta who are not of Betawi ethnicity and do not have moderate or fluent Betawi language competence, with ages between 13 and 23 years who have different educational backgrounds and gender, consisting of 25 people as research subjects.

The data collection techniques used in the present study were tapping techniques and listening techniques in language, which included competent free listening techniques, recording techniques, and note-taking techniques. After this data is collected, data analysis techniques are carried out by transcribing the recorded data in written language, identifying and classifying the data based on aspects of affixation, reduplication, and composition and the acronym, interpreting the data, and then concluding the data.

\section{Results and Discussion}

Based on the research findings, the following describes a discussion of research data with respect to morphological systems, interference that can occur in the fields of phonology, morphology, syntax, and semantics. Morphology as part of linguistics is tasked with solving problems related to grammatical word-formation. In Indonesian and Javanese, some affixes or affixes play an important role in word-formation. Through affixation, various meanings will be created from one basic form.

In research, it was found that interference often occurred in adolescents who used two or more languages interchangeably for different purposes. The greater the number of people like this, the more intensive the bilingual contact they use. This contact causes mutual influence that manifests in applying the rules of the first language (B1) in the use of the second language (B2). The opposite situation can also occur in the use of a second language (B2) when using B1. Nonlinguistic factors contribute to the use of language, including interference symptoms. Nonlinguistic factors that most influence language use are social and situational factors.

In connection with this research, too, adolescents often use two languages side by side. This is because their emotions are still unstable, so they tend to imitate. The findings of the current study indicate that there is morphological interference of the Betawi language to speech morphology from the aspects of affixation and reduplication, which are described below. 


\section{A. Affix}

An affix is a bound unit (a certain set of letters) that will change the meaning and form a new word when added to the root word. Affixes cannot stand alone and must be attached to other units, such as a root. In the present study, aspects of confix, prefix, nasal prefix, and suffix found in the Betawi language interference with similarities and differences in standard Indonesian.

\section{Confix}

Confix is an affix that consists of a prefix and a suffix that is placed between the root words.

Table 1. Betawi dialect interference in the aspect of confixes

\begin{tabular}{|l|l|l|l|l|}
\hline No & Kata Dasar & \multicolumn{1}{|c|}{$\begin{array}{c}\text { Interferensi Dialek } \\
\text { Betawi }\end{array}$} & Bahasa Indonesia Baku & English \\
\hline 1 & Tunjuk & Nunjukin & Menunjukan & Showing \\
\hline 2 & Lihat & Ngeliatin & Melihat & Look \\
\hline 3 & Tinggal & Ketinggalan & Tertinggal & Left behind \\
\hline 4 & Duduk & Kedudukan & Terduduki & Occupied \\
\hline 5 & Ambil & Ngambil & Mengambil & Take \\
\hline 6 & Waris & Ngewarisin & Mewariskan & Pass down \\
\hline 7 & Hormat & Ngormatin & Menghormati & Respect \\
\hline
\end{tabular}

Note: The confixes of $m e-i$ and $m e-k a n$ in Indonesian are replaced by $n g$-in in Betawi.

2. Prefix

A prefix or prefix is an affix that is affixed at the beginning of a root word. The findings of the current study indicate that there is morphological interference of Betawi language to the morphological variables of adolescent speech in Jakarta from the aspect of affixation. In this case, the researcher found affixations in the form of prefixes, suffixes, and confixes. However, the researcher did not find any affixations with infixes in the speech construction.

The findings of the present study indicate that there are words that are affixed with a prefix, and the researcher argues that the prefix is marked by an affix that is affixed to the left of the root word, reinforced by the existence of Verhaar's theory (2004: 107) that states that a prefix is an affix added next to it, left a base in a process called "prefixation." In addition, Chaer (2008: 23) said that prefixes are affixes that are affixed to the left of the basic form, namely, prefix ber-, prefix me, prefix per-, prefix $d i$, prefix ter-, and prefix ke-.

Table 2. Betawi dialect preferences in the aspect of prefixes

\begin{tabular}{|l|l|l|l|l|}
\hline No & Kata Dasar & \multicolumn{1}{|c|}{$\begin{array}{c}\text { Interferensi Dialek } \\
\text { Betawi }\end{array}$} & Bahasa Indonesia Baku & English \\
\hline 1 & Ledak & Meleduk & Meledak & Exploded \\
\hline 2 & Dorong & Kedorong & Didorong & Pushed \\
\hline 3 & Sandar & Nyender & Bersandar & Lean back \\
\hline 4 & Telan & Ketelen & Tertelan & Swallowed \\
\hline 5 & Kumpul & Ngumpul & Berkumpul & Get together \\
\hline
\end{tabular}

\section{Nasal prefixes $(\mathrm{Ng}-),(\mathrm{Ny}-)$}

The current study results indicate the presence of the Betawi language morphology on the morphological variables of adolescent speech in Jakarta from the affixation aspect that is affixed with the prefix spoken by the speakers. In this case, the researcher found that words with a prefix appeared in a small number, namely, / ng-, ny-, and n- /, which can be seen in the following data. In this case, many speakers mix up the Betawi language in their speech, resulting in an imbalance of speech by teenagers in Jakarta. The process of an imbalance in a speech by affixing the prefix with the Betawi language pattern. This is due to adolescents' age, and their emotional state is still unstable, so these adolescents tend to mix up languages. This is what triggers the interference.

Table 3. Betawi dialect interference in the aspect of nasal prefixes

\begin{tabular}{|l|l|l|l|l|}
\hline No & Kata Dasar & \multicolumn{1}{|c|}{$\begin{array}{c}\text { Interferensi Dialek } \\
\text { Betawi }\end{array}$} & Bahasa Indonesia Baku & English \\
\hline 1 & Sebal & Nyebelin & Menyebalkan & Resent \\
\hline 2 & Hibur & Ngibur & Menghibur & Cheer up \\
\hline 3 & Sahut & Nyaut & Menyahut & Reply \\
\hline 4 & Kumpul & Ngumpul & Mengumpul & Gather \\
\hline
\end{tabular}




\begin{tabular}{|l|l|l|l|l|}
\hline 5 & Korek & Ngorek & Mengorek & Pick up \\
\hline 6 & Intip & Ngintip & Mengintip & Peek \\
\hline 7 & Supir & Nyupirin & Menyupirkan & Muck \\
\hline 8 & Antar & Nganter & Mengantar & Deliver \\
\hline 9 & Sadar & Nyadar & Menyadari & Be aware \\
\hline 10 & Rasa & Ngerasa & Merasa & Feel \\
\hline
\end{tabular}

4. Suffix

A suffix or suffix is an affix that is affixed at the end of a word. The current study's findings indicate the Betawi language morphological interference to the morphological variables of adolescent speech in Jakarta from the affixation aspect affixed with a suffix. In this case, the researcher found that adolescents in Jakarta tended to use the Betawi language that was affixed with this suffix.

The affix that attaches the root word above is the suffix -in. The suffix -in is affixed with the basic word know to become the word tahuin. The suffix -an with the root word dissolves into the word dissolve. From the data found by the researcher, the viewpoint appears that the suffix is the affix that is added to the right of the root word. This is in line with the theory put forward by Verhaar (2004: 107) that a suffix is an affix that is added to the right of the base in a process called "suffixation." Furthermore, Chaer (2008: 23) said that a suffix is an affix that is affixed to the right of the basic form, namely, $-k a n,-i,-a n$, and so on.

In this case, the researcher assumes that the morphological interference of the Betawi language to the morphological variables of adolescent speech in Jakarta occurs because of their lack of understanding of standard Indonesian. Teenagers understand and can speak Indonesian, but the Indonesian language used is Betawi Malay. The inaccuracy of choosing Indonesian vocabulary from the Minangkabau language used is one part of the interference.

Table 4. Betawi dialect interference in the aspect of suffixes

\begin{tabular}{|l|l|l|l|l|}
\hline No & Kata Dasar & \multicolumn{1}{|c|}{$\begin{array}{c}\text { Interferensi Dialek } \\
\text { Betawi }\end{array}$} & Bahasa Indonesia Baku & English \\
\hline 1 & Arep & Arepin & Berharap & Hope \\
\hline 2 & Ambek & Ambekan & Mengambek & Sulk \\
\hline 3 & Antep & Antepin & Membiarkan & Let \\
\hline 4 & Bentar & Bentaran & Sebentar & Just a second \\
\hline 5 & Pantes & Pantesan & Pantas/Memantas & Deserve \\
\hline 6 & Sono & Sonoan & Sana & There \\
\hline 7 & Benah & Benahin & Berbenah & Clean up \\
\hline 8 & Datang & Datengin & Mendatangkan & Bring in \\
\hline 9 & Pasang & Pasangin & Memasangkan & Pair \\
\hline 10 & Dadak & Dadakan & Mendadak & Sudden \\
\hline
\end{tabular}

Note: The suffixes - $i$ and -kan in Indonesian change to the suffix -in in Betawi.

\section{B. Reduplication}

The process of repetition or reduplication is the repetition of grammatical units, either in whole or in part, whether with variations of the phoneme or not. The result of the repetition here is called the repeating word, whereas the repeated unit is the basic form. The Betawi people show their uniqueness by saying many words with the phoneme a to e, the phoneme $u$ being $o$, and the phoneme o being $u$.

The present study's findings indicate that there is morphological interference of Betawi language to the morphological variables of adolescent speech in Jakarta from the reduplication aspect. Based on the current study results, the researcher found the Betawi language morphological interference to the morphological variables of adolescent speech in Jakarta from the reduplication aspect, namely, dwilingga. It can be seen from the research data obtained by speakers that it is clear that there is a lack of vocabulary, such as the word nungging that was adopted from the Betawi Malay language. This is what causes interference. Teenagers can use the language properly and correctly, both Indonesian. However, speakers tend to mix up the language, which results in interference.

The researcher classifies the data that the researcher has found above into dwilingga groups from the data above. The grouping carried out by the researcher is based on the theory stated by Verhaar (2004: 152) that dwilingga, namely, the repetition of the original morpheme, as in (Indonesian) tables, forget-forgetting, children, free, and so on. 
Table 5. Reduplication in Betawi language

\begin{tabular}{|l|l|l|l|}
\hline No & \multicolumn{1}{|c|}{ Bahasa Betawi } & \multicolumn{1}{|c|}{ Bahasa Indonesia } & \multicolumn{1}{c|}{ English } \\
\hline 1 & Ambak-ambakan & Berantakan & A mess \\
\hline 2 & Temen-temen & Teman-teman & Friends \\
\hline 3 & Inget-inget & Ingat-ingat & Just remember \\
\hline 4 & Ngumpul-ngumpul & Kumpul-kumpul & Gather together \\
\hline
\end{tabular}

\section{Discussion}

The results showed the Betawi language morphological interference to the morphological variables of speech from the aspects of affixation and reduplication. The present study's findings indicate that there is morphological interference of the Betawi language to the morphological variables of speech from the aspect of affixation, namely, words affixed with prefixes, suffixes, and confixes. The current study's findings also indicate that there is morphological interference of the Betawi language to the morphology of speech from the reduplication aspect, namely, dwilingga. Hortman and Stoork in Alwasilah (1985: 131) consider interference as a mistake due to the carrying over of the spoken habits of the mother tongue or dialect into the second language or dialect. Speakers unconsciously use regional languages when speaking in the context of Indonesian. Speakers can avoid this because the mother tongue words used by bilinguals already have their equivalents in Indonesian. Language interference that occurs due to the speaker's habit of using regional languages can be seen in word-formation (morphology) and sentence structure (syntax).

\section{Conclusion}

Based on the research findings and discussion that have been carried out in the present study, it is known that teenagers in Jakarta often use Betawi language elements in their communication. The findings of the current study indicate that there is morphological interference of the Betawi language to the morphological variables of speech from the aspects of affixation and reduplication. The present study's findings indicate that there is morphological interference of the Betawi language to the morphological variables of speech from the aspect of affixation, namely, words that are spiked with prefixes, suffixes, and confixes. The current study's findings also indicate that there is morphological interference of the Betawi language to the morphology of speech from the reduplication aspect, namely, dwilingga. There is an anomaly in the assumption; namely, the researcher did not find any interference with the morphology of the Betawi language on the morphology of speech from the aspects of composition and the acronym spoken by teenagers in Jakarta. It was also found that there are assumptions and perspectives in the psychology of speakers that the Betawi language is an inseparable part of speech construction in the Jakarta area. Thus, the application of code-switching and mixing the Betawi language code by teenagers in Jakarta is common with a maximum level of understanding.

This research is still limited to capturing the actual picture of the strength and influence of the Betawi language in the communication of the dominant users, namely teenagers. Henceforth, it is highly recommended to start diagnosing the health condition of the Betawi language as a whole, to be able to decide on the most effective and efficient solution for saving and recovering the Betawi language. The big vision of this program is to explore Betawi cultural values and technology that have been hidden and not utilized optimally.

\section{References}

[1] Alwasilah, A. C. (1985). Beberapa Madhab dan dikotomi Teori Linguistik. Bandung: Angkasa.

[2] Ardiana, L. I. (1990). Analisis kesalahan Berbahasa. FPBS IKIP Surabaya.

[3] Bawa, I. W. (1981). "Pemakaian Bahasa Indonesia yang Baik dan Benar". Denpasar: Jurusan Bahasa dan Sastra Indonesia Fakultas Sastra Universitas Udayana.

[4] Chaer, A. (1994). Linguistik Umum. Jakarta: Rineka Cipta.

[5] Chaer, A. \& Agustina, L. (1995). Sosiolinguistik Perkenalan Awal. Jakarta: Rineka Cipta.

[6] Huda, Nuril dkk. (1981). Interferensi Bahasa Madura Terhadap Bahasa Indonesia Tulis Murid Sekolah Dasar Jawa Timur.Jakarta. Pusat Pembinaan dan Pengembangan Bahasa.

[7] Hayi, Abdul dkk. (1985). Interferensi Gramatika Bahasa Indonesia dalam Bahasa Jawa. Jakarta. Pusat Pembinaan dan Pengembangan Bahasa.

[8] Jendra, I. W. (1991). Dasar-Dasar Sosiolinguistik. Denpasar: Ikayana.

[9] Kridalaksana, H. (1998). Introduction to Word Formation and Word Classes. Jakarta. Universitas Indonesia.

[10] Moleong, J. L. (2010). Metodologi Penelitian Kualitatif. Bandung: Remaja Rosda.

[11] Nababan. P.W.J. (1984). Sosiolingustik. Jakarta: Gramedia.

[12] Nazir, M. (2009). Metode Penelitian. Jakarta: Ghalia Indonesia.

[13] Suwito. (1985). Pengantar Awal Sosiolinguistik: Teori dan Problema. Surakarta: Henary Cipta.

[14] Yusuf, S. \& Sugandhi, N. M.. (2011). Perkembangan Peserta Didik: Mata Kuliah Dasar Profesi (MKDP) bagi Para Mahasiswa Calon Guru di Lembaga Pendidikan Tenaga Kependidikan (LPTK). Jakarta: Raja Grafindo Persada. 